Agha Usama Hasan, I University of West London, UK

\title{
COVID-19 AND EDUCATION ECONOMICS IN THE UK
}

\author{
Considering the effect of COVID-19 on the UK's higher \\ education system
}

$\mathrm{S}$ truggling for a second consecutive year in 2021, the world is still attempting to cope with the coronavirus. Of particular concern is the impact of a pandemic of such an enormous scale on the cross-border, international movement of people exploring more promising economic avenues and educational opportunities. Curtailing free movement and imposing a huge financial strain, the pandemic has especially hindered the ability of international students to access higher education in Western Europe. The UK's higher education system has by no means remained untouched by the scourge of the virus, with almost $56 \%$ of the Tier- 4 visa participants in a recent survey expressing displeasure and indeed fear regarding their international student status (Migrants' Rights Network, 2020). They cited increasing financial pressures and a conspicuous absence of support structures from higher education providers. As such, the very atmosphere of higher education for international students may deteriorate further, triggering the decline of the UK as a preferred academic destination. The impact of COVID-19 on international students and the consequent hardships they are facing have been documented. However, few attempts have been made to consider the disruptive effect of the pandemic on educational finances and the loss of academic appeal for overseas students, which countries such as the UK aspire to maintain. This present piece is an attempt in that direction, to reveal the various functional interlinkages between a ferocious pandemic, international student finances, educational economics and the overall influences of these factors on a nation's soft power projection through its hallowed institutions.
Pandemic and the international students in the UK

Continuing through 2020 into 2021, the COVID-19 pandemic has had a crippling effect on everyday life. The exponential rise of cases in 2020 forced the British government to adopt stringent lockdown measures (Landler \& Castle, 2020). Whole cities were shut down, people were forced to remain in their homes, cross-border travel was severely restricted, and gatherings were curbed. It was sadly inevitable that the migrant portion of the population would bear the brunt of the lockdown. Having left their home countries in search of better educational and economic opportunities, migrants in the UK were vulnerable. Many lost their livelihoods and employment to COVID-19 restrictions, as many migrants were employed in sectors which were hit hardest by pandemic-related closures. For example, $30 \%$ of employees in hospitality and $28 \%$ in the logistics sector were migrants (The Migration Observatory, 2021). Furthermore, statistics show that the share of migrants in the UK's workforce declined from $18 \%$ in 2019 to $16 \%$ in 2020 . This led in turn to increasing financial insecurity and declining socio-economic development for this section of the population. The unemployment rate also increased for migrants, from $5 \%$ in 2019 to almost $8 \%$ in 2020. Migrants are more likely to be employed in temporary contractual jobs, which offer much less security than those employing their UK-born counterparts (The Migration Observatory, 2021).

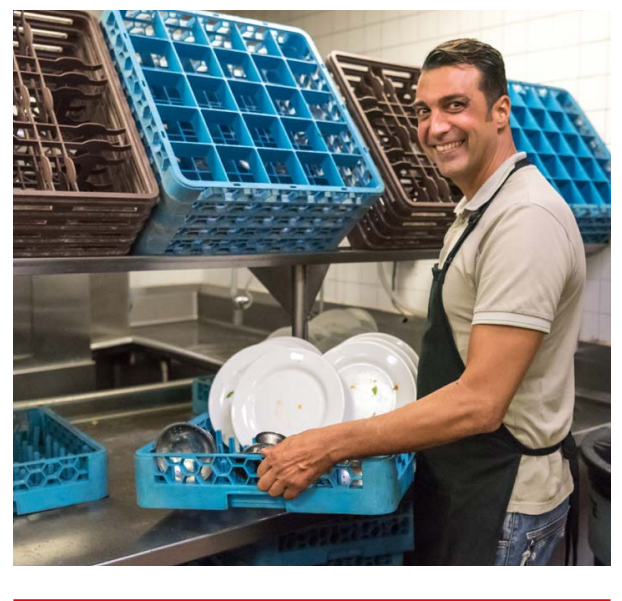

Statistics show that the share of migrants in the UK's workforce declined from $18 \%$ in 2019 to $16 \%$ in 2020 


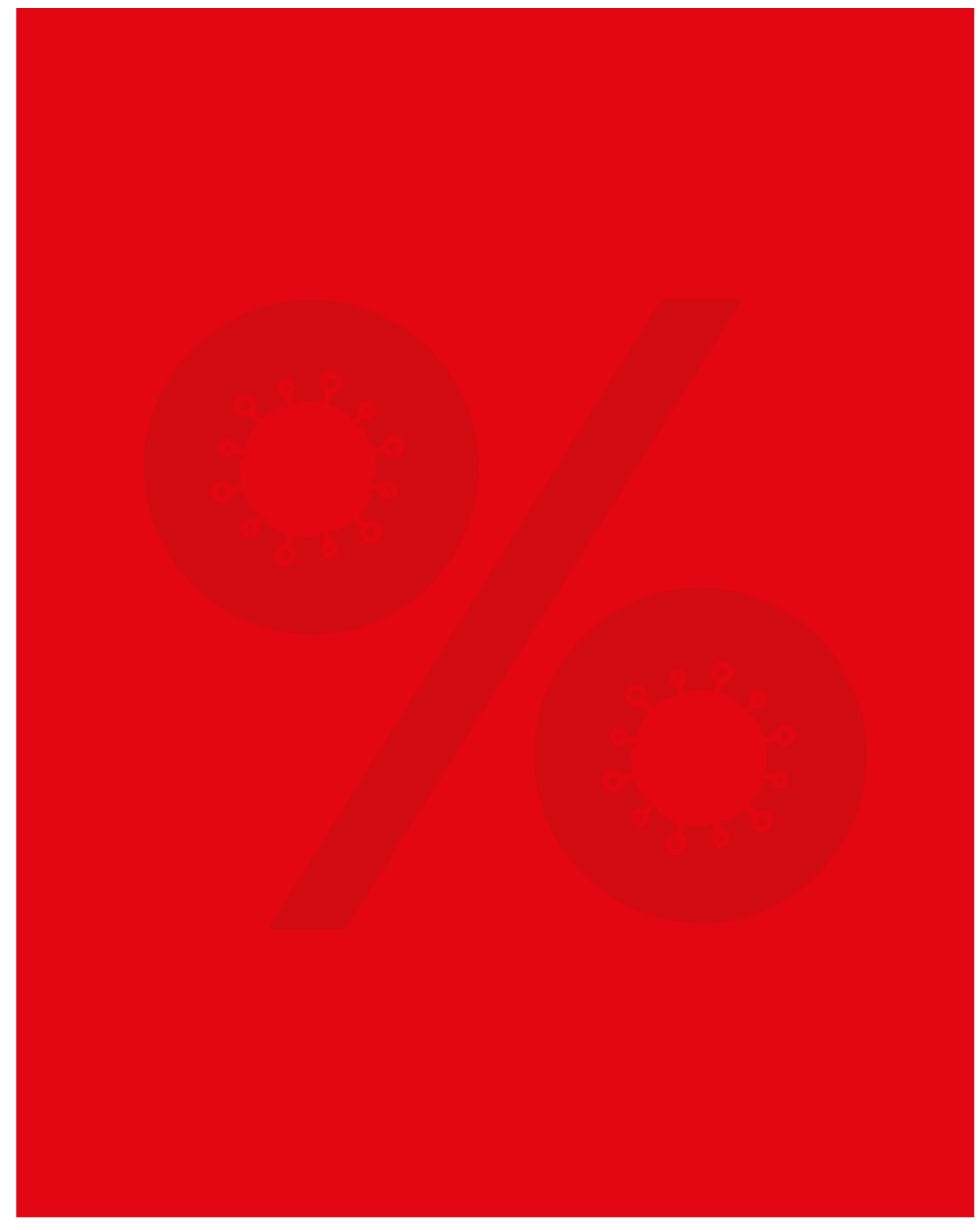

9 New Vistas - Volume 7 Issue 2 - www.uwl.ac.uk • University of West London 
Tuition from international students contributes 17\% of the nearly 40 billion GBP earnings of the higher education sector

Amongst migrants in the UK, however, it has been the international Tier- 4 visa students who have faced additional pressures, both tangible and intangible. This is due to the fact that, apart from facing socio-economic disparities and possible exclusionary and discriminatory practices in a foreign land, students often have to rely on financial support from their home countries (Migrants' Rights Network, 2020). And with the developing world accounting for almost $60 \%$ of global GDP losses (United Nations Conference on Trade and Development, 2021), particularly for students who have come to the UK from developing countries, diminishing family income owing to COVID-19 has highlighted the possibility of suspension or even expulsion of students over non-payment of fees. The existence of a "No-Recourse to Public Funds" policy for Tier-4 students and lack of a uniform fee amnesty response from the government has in turn amplified the woes of the already anxious international student community in the UK (Migrants' Rights Network, 2020). However, the virus's impact is not limited to current migrant students. It has also exposed the vulnerabilities of the UK's higher education system, more specifically its finances. Tuition from international students contributes $17 \%$ of the nearly 40 billion GBP earnings of the higher education sector. This amounts to almost 7 billion GBP. Accordingly, a loss of international students would have serious fiscal implications for the UK's higher educational institutions (Popov \& Isard, n.d.). Another immediate impact of the pandemic has been the collapse of local economies that depended on consumption-based ecosystems generated by educational hubs in the country. With COVID-19related restrictions in place, many international students have been unable to pay for accommodation in the UK. They instead are opting to attend to their academic obligations from their home countries through virtual learning. Educational hubs in small settlements such as Sussex and Brighton essentially fuel the local economy; every expense a student has, be it for accommodation, food or recreation, sustains these small population centres across the UK. With students being forced to opt for online teaching, the businesses that relied on once bustling student activities have been facing the heat of this pandemic.

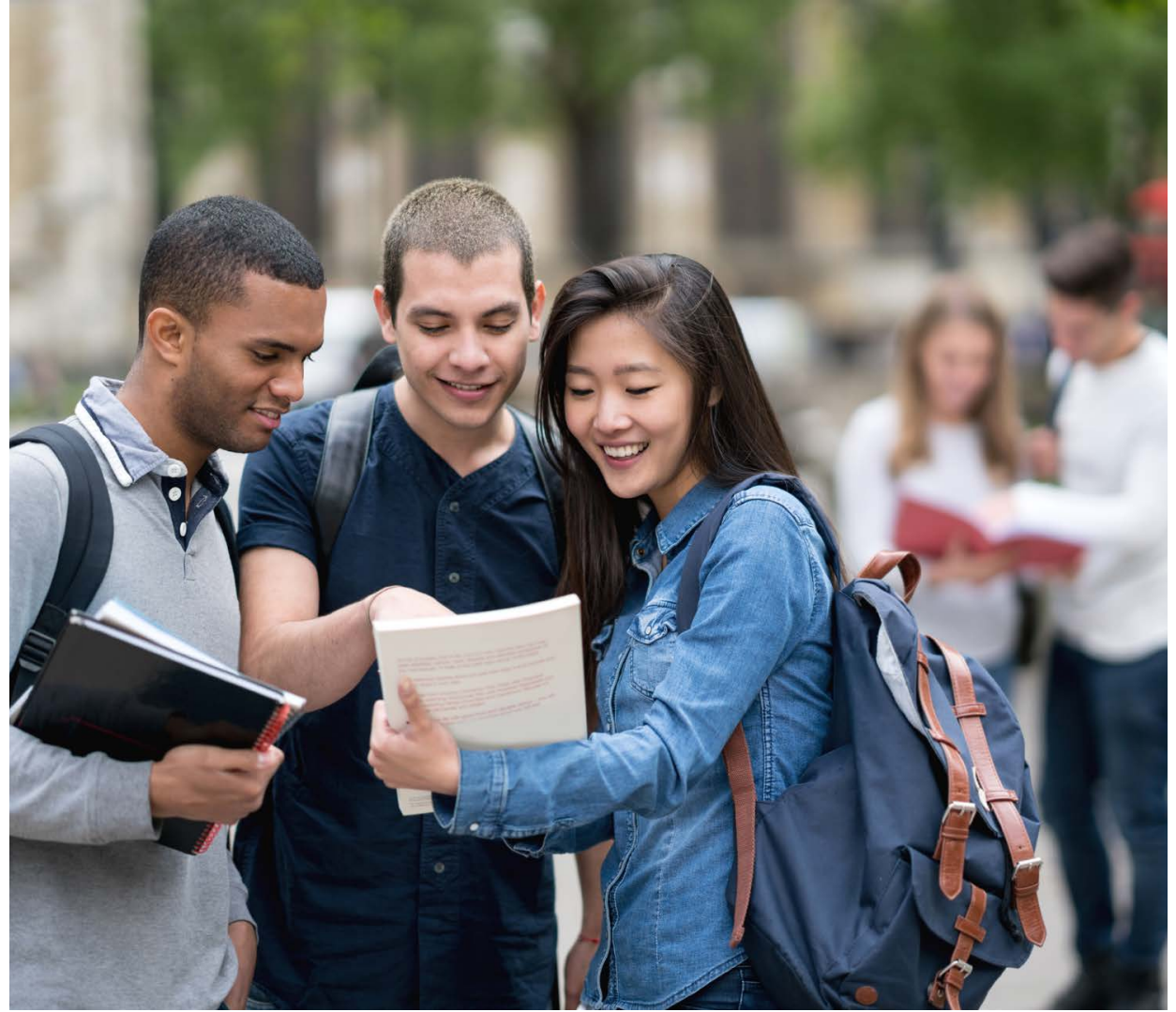

\section{Post-pandemic recovery and the future of the higher education system in the UK}

The higher education (eco)system of any nation forms the foundation upon which its socio-economic, political, and diplomatic standing rests. The strength of a country's higher education system, and more so that of the infrastructure of tertiary education, exerts a decisive influence on the progression or retardation of teaching instructions, learning outcomes and employability (Teixeira, Amoroso \& Gresham, 2017). The European Union's strategic framework for Education and Training (2020) also stresses that a healthy and sustainable higher educational system should be endowed with adequate financial support, along with a guarantee that will safeguard financial inflow from major fluctuations. For without finances, the institutions will suffer from quality degradation due to a decline in faculty involvement, disintegration of infrastructure, and disenchanted students. As such, the COVID-19 pandemic, with its rising human and economic costs, has the capability to subvert the UK's national higher education profile.

COVID-19 has been seen as a public health crisis on a global scale, sending shockwaves through leading nations of the West such as the US and the UK, upending existing worldwide norms and uprooting normal lives. Subsequently, the post-pandemic era has attracted attention to the resilience of the very essence of the higher education system in the world in general and the UK in particular. The higher education system has not only an economic role to play in terms of enhancing employability and ensuring

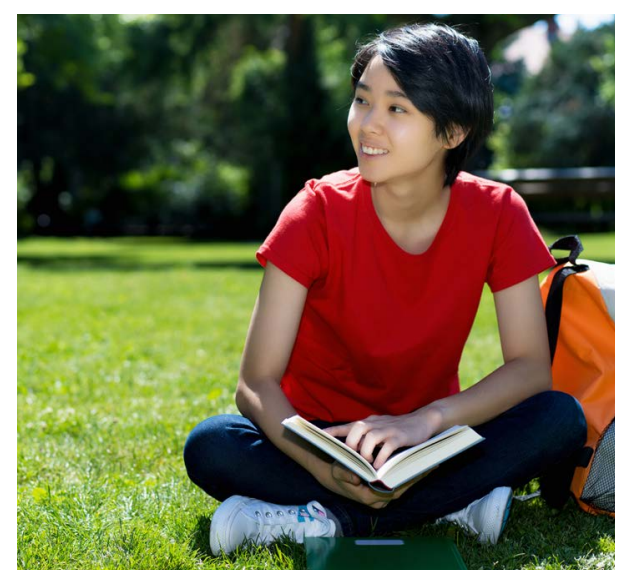




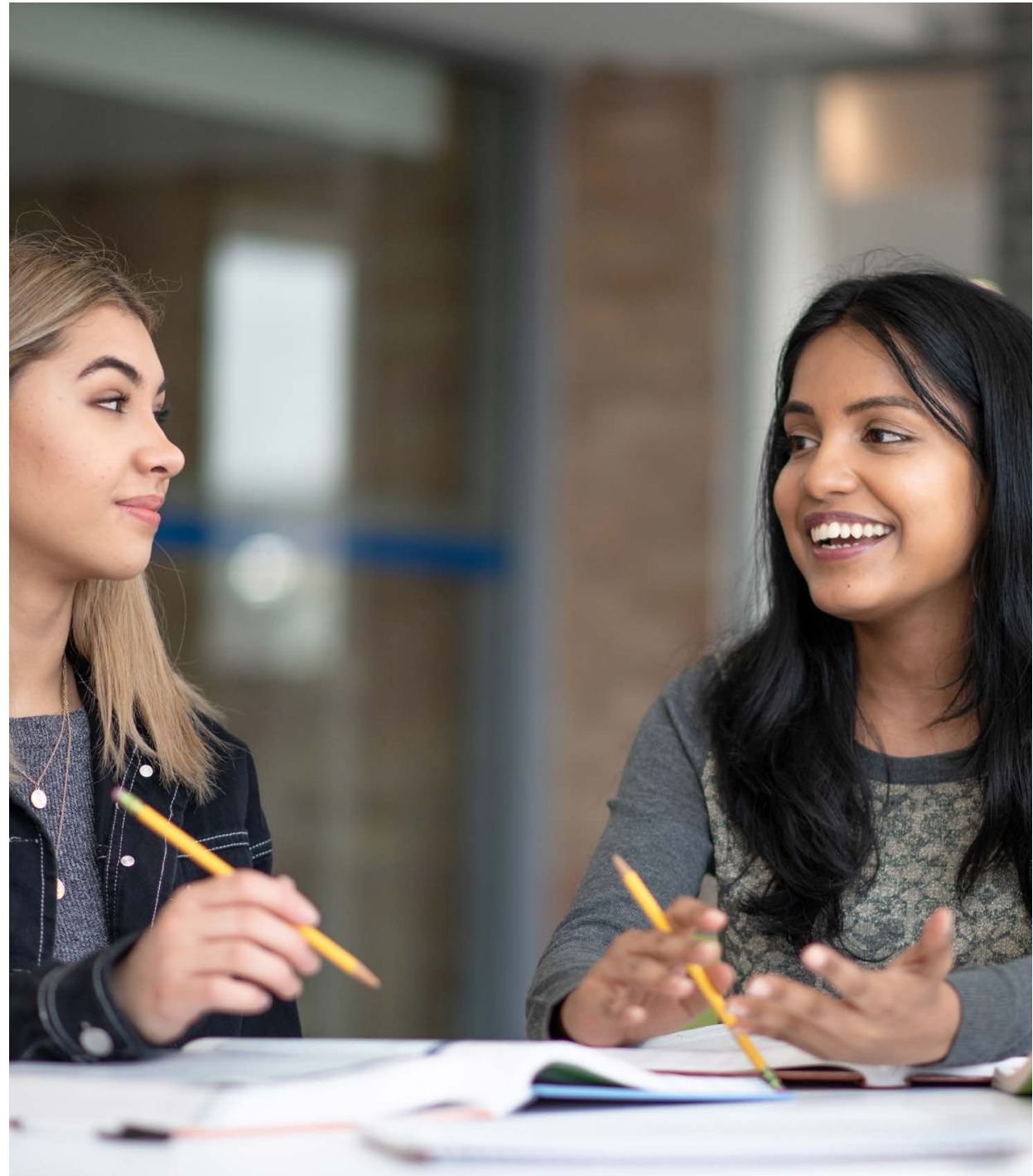

technological progress, along with enriching a nation's political and social profile, it also has a moral obligation to promote democratic thinking and provide solutions to shocks such as those caused by the pandemic, as suggested by Ira Harkavy, Associate Vice President of the University of Pennsylvania (Penn Today, 2021). The pandemic has evidently exposed the existing socio-economic vulnerabilities and disparities in the social base and created the challenge of finding innovative solutions to the higher educational system, which is already reeling under the effect of the virus. Therefore, in view of the pressures imposed by the pandemic and the rising importance of higher education institutions, the post-pandemic age offers both opportunities as well as dangers in term of sustaining the high quality education offered in Western countries such as the UK.

One of the primary issues discussed above is the financial blow to the higher educational institutions. In a post-pandemic age, these institutions not only have the responsibility to cater to the educational demands of the population. They should also serve as centres for excellence in research and development and continuously nurture innovation, promote growth, and bolster academic progress. Reducing the attractiveness for international students especially, and transitioning to a completely virtual mode of learning will indeed impact these intertwined objectives of the UK's higher education system. Moreover, the crosssubsidisation model that the UK institutions follow, for example offering higher education to UK the higher fees charged to international students, is bound to come under pressure. Furthermore, with many specialised departments deriving their remuneration through the income from international students and specific international research funding, their future prospects remain bleak, and very much subject to the environment created by the pandemic. citizens at a lower fee, essentially subsidised by

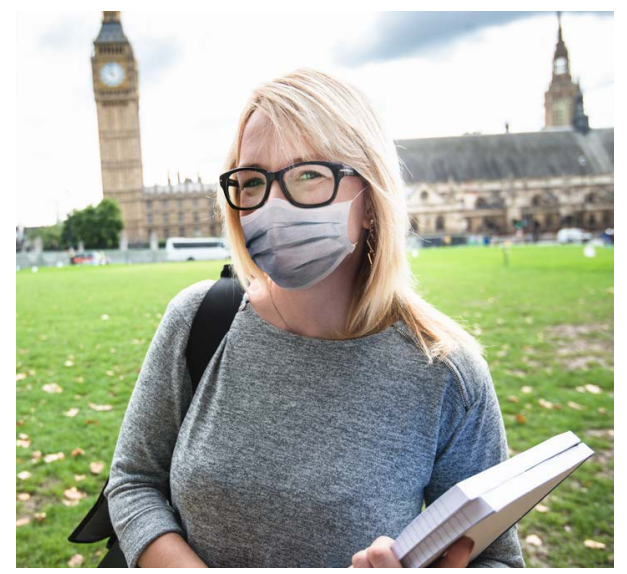

\section{Conclusion}

Beyond any doubt, the pandemic and its aftermath have reduced the prosperity of the UK's higher education institutes, with higher education now facing more deficiencies than ever before. The lack of reliable and efficient financial resources, coupled with declining educational standards due to promotion of impersonal and remote modes of learning through virtual media, has further distorted the norms of offering educational learning. This in turn increases the possibility of international student enrollment declining and the associated declining income that was supported by the UK's reliance on international students. The effect on local economies, as well as large-scale institutional financing of higher education institutions, will reverberate through the next few years. Therefore, it devolves on the state to provide much-needed innovative answers to the potential or even pending destruction of the UK's higher education system.

One of the first solutions the state could implement to reduce its overt reliance on income derived from international students is fee rationalisation. Since $30 \%$ of higher education income is sourced solely from international students, a reduced attractiveness of the UK's world class facilities needs to be countered by a policy of unshackling cross-subsidisation and moving towards an equitable fee structure, where domestic students are charged fees comparable to their international counterparts. This policy would ensure that fees from domestic students act as a cushion, which will brace the UK educational system for the otherwise sharp reductions due to declining enrolment from abroad. Another solution, which in the UK's case could be particularly effective, is the promotion of academia-industry interlinkages. By enhancing the prospects of employment for graduates and 


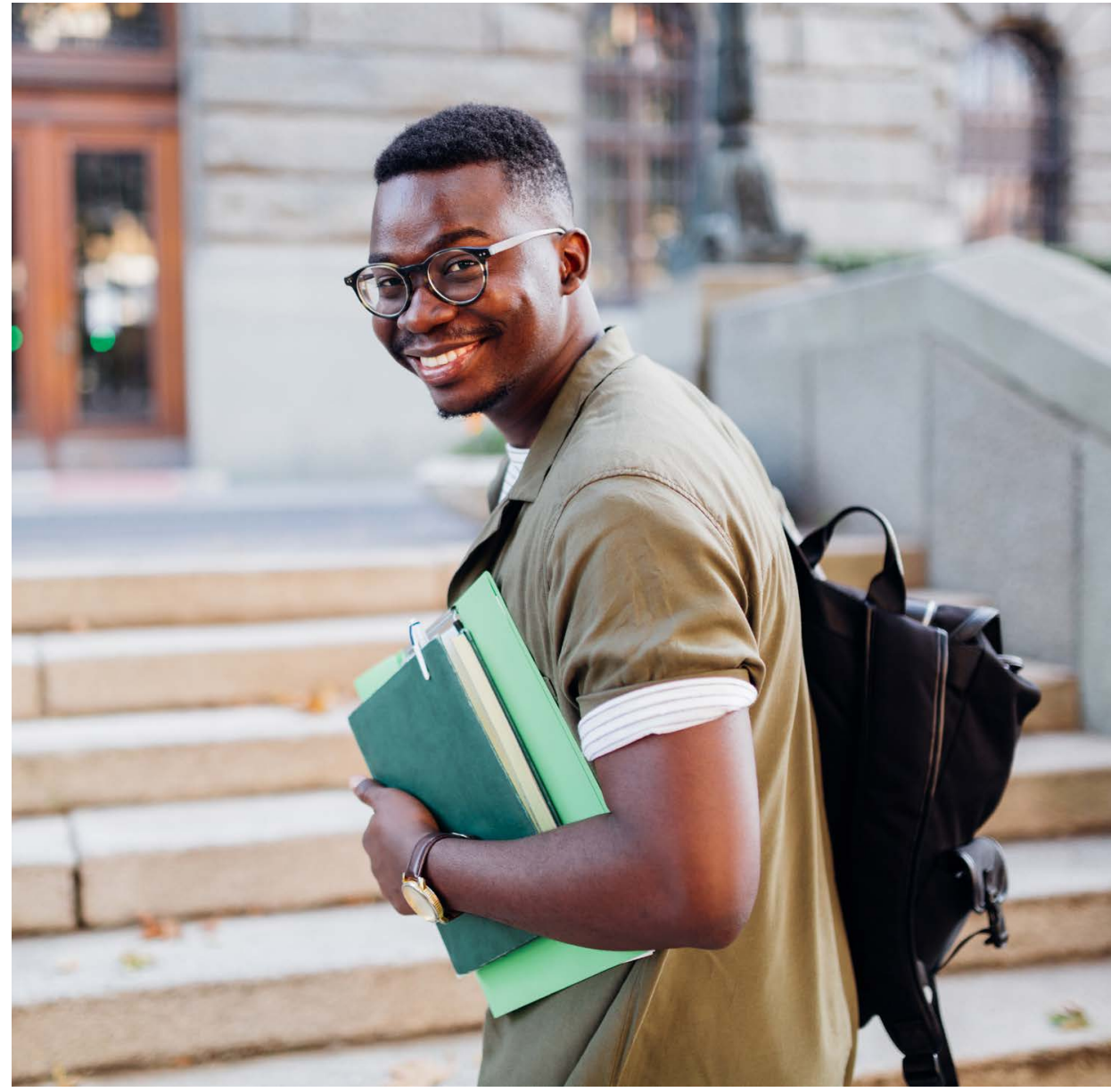

In comparison to the US, where healthcare is highly privatised, the UK is more capable of offering international students extensive COVID-19 protection coverage through the National Health Service. This will further ensure healthcare outreach and thus lead to increased international student enrollment research scholars who prefer to complete their education in the UK, such a step should maintain the attractiveness of the UK higher education system. Furthermore, in comparison to the US, where healthcare is highly privatised, the UK is more capable of offering international students extensive COVID-19 protection coverage through the National Health Service. This will further ensure healthcare outreach and thus lead to increased international student enrollment. Finally, UK higher education institutions must intricately devise and conceptualise structures that will provide safeguards to the international student community. The prevailing lack of such structures has driven a perceptible animosity towards the institutions on the part of international students.

The pandemic remains alarmingly rampant at the time of writing; the coronavirus's new delta variant is poised to bring even more challenges to an already overburdened, troubled and disturbed higher education system in the UK. However, concrete and viable steps can ensure that the pillars of higher education remain solid and intact, despite the 'new normal' being imposed by the virus. After all, wisdom, equity, and justice must prevail in the UK's adjustment to the new realities on the ground.

\section{References}

Education and Training (2020) Effective and Efficient Higher Education. Retrieved from https://ec.europa.eu/ education/policies/higher-education/effective-andefficient-higher-education_en

Landler, M. \& Castle, S. (2020) Boris Johnson Tightens UK Lockdown, Citing Fast-Spreading Version of Virus. The New York Times, 19 December. Retrieved from https://www. nytimes.com/2020/12/19/world/europe/coronavirus-uknew-variant.html

Migrants' Rights Network (2020) Study: The Effect of Covid-19 on Tier-4 International Students August 2020 Migrants' Rights Network, 10 August. Retrieved from https://migrantsrights.org.uk/2020/08/10/study-thehttps://migrantsrights.org.uk/2020/08/10/study-the-
effects-of-covid-19-on-tier-4-international-students/ Penn Today (2021) Exploring the future of higher education. Retrieved from https://penntoday.upenn.edu/ news/future-higher-education

Popov, D. \& Isard, A. (n.d.) U.K Higher Education and Covid-19. Retrieved from http://www.frontier-economics. com/uk/en/news-and-articles/articles/article-i7536-ukhigher-education-and-covid-19/

Teixeira, J., Amoroso, J. \& Gresham, J. (2017) Why Education Infrastructure Matters for Learning. World Bank Blogs, 3 October. Retrieved from https://blogs.worldbank. org/education/why-education-infrastructure-matterslearning

The Migration Observatory (2021) Migrants in the UK Labour Market: An Overview. The Migration Observatory, 11 January. Retrieved from https://migrationobservatory. ox.ac.uk/resources/briefings/migrants-in-the-uk-labourmarket-an-overview/

United Nations Conference on Trade and Development (2021) Global Economy could lose over USD 4 Trillion due to Covid-19 impact on Tourism. Retrieved from https:// unctad.org/news/global-economy-could-lose-over-4-trilliondue-covid-19-impact-tourism

\section{About the author}

Agha Usama Hasan is a PhD student in the School of Computing and Engineering at the University of West London, and works as a Parliamentary Researcher in the House of Commons.

\section{Key words}

COVID-19, higher education, education finances, international students, immigration

This is an open access article under the terms of the Creative Commons Attribution License (https://creativecommons.org/ licenses/by/4.0/), which permits use, distribution and reproduction in any medium, provided the original work is properly cited. () The Authors. New Vistas Published by University of West London.

The design, art direction and photography elements remain the intellectual property of the copyright holders and are not included in the Creative Commons Attribution license applied to the rest of this work. Photographs \& illustrations (C) Jebens Design Ltd (Jebens Design - www.jebensdesign co uk) Cover Photography (Claire Williams Photography - www. (lairewilliamsphotography.co.uk). 